\title{
Article \\ Glyphosate and AMPA Induce Alterations in Expression of Genes Involved in Chromatin Architecture in Human Peripheral Blood Mononuclear Cells (In Vitro)
}

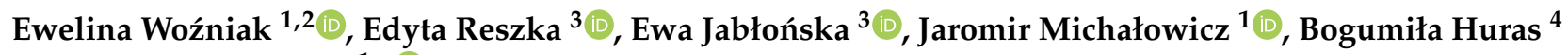 \\ and Bożena Bukowska ${ }^{1, *(D)}$
}

1 Department of Biophysics of Environmental Pollution, Faculty of Biology and Environmental Protection, University of Lodz, Pomorska 141/143, 90-236 Lodz, Poland; ewelina.wozniak@umed.lodz.pl (E.W.); jaromir.michalowicz@biol.uni.lodz.pl (J.M.)

2 Laboratory of Tissue Immunopharmacology, Department of Internal Diseases and Clinical Pharmacology, Medical University of Lodz, Kniaziewicza 1/5, 91-347 Lodz, Poland

3 Department of Molecular Genetics and Epigenetics, Nofer Institute of Occupational Medicine, Teresy 8, 91-348 Lodz, Poland; Edyta.Reszka@imp.lodz.pl (E.R.); Ewa.Jablonska@imp.lodz.pl (E.J.)

4 Łukasiewicz Research Network, Institute of Industrial Organic Chemistry, Annopol 6 Str, 03-236 Warsaw, Poland; bogumila.huras@ipo.lukasiewicz.gov.pl

* Correspondence: bozena.bukowska@biol.uni.lodz.pl

Citation: Woźniak, E.; Reszka, E.; Jabłońska, E.; Michałowicz, J.; Huras, B.; Bukowska, B. Glyphosate and AMPA Induce Alterations in Expression of Genes Involved in Chromatin Architecture in Human Peripheral Blood Mononuclear Cells (In Vitro). Int. J. Mol. Sci. 2021, 22, 2966. https://doi.org/10.3390/ ijms22062966

Academic Editors: Antonietta Santoro and Giovanna Della Porta

Received: 12 February 2021

Accepted: 12 March 2021

Published: 15 March 2021

Publisher's Note: MDPI stays neutral with regard to jurisdictional claims in published maps and institutional affiliations.

Copyright: (c) 2021 by the authors. Licensee MDPI, Basel, Switzerland. This article is an open access article distributed under the terms and conditions of the Creative Commons Attribution (CC BY) license (https:// creativecommons.org/licenses/by/ $4.0 /)$.

\begin{abstract}
We have determined the effect of glyphosate and aminomethylphosphonic acid (AMPA) on expression of genes involved in chromatin architecture in human peripheral blood mononuclear cells (PBMCs). The cells were incubated with glyphosate and AMPA in the concentrations ranging from 0.5 to $100 \mu \mathrm{M}$ and from 0.5 , to $250 \mu \mathrm{M}$, respectively. The expression profile of the following genes by quantitative Real-Time PCR was evaluated: Genes involved in the DNA methylation (DNMT1, $D N M T 3 A$ ) and DNA demethylation process (TET3) and those involved in chromatin remodeling: genes involved in the modification of histone methylation (EHMT1, EHMT2) and genes involved in the modification of histone deacetylation (HDAC3, HDAC5). Gene profiling showed that glyphosate changed the expression of DNMT1, DMNT3A, and HDAC3, while AMPA changed the expression of DNMT1 and HDAC3. The results also revealed that glyphosate at lower concentrations than AMPA upregulated the expression of the tested genes. Both compounds studied altered expression of genes, which are characteristic for the regulation of transcriptionally inactive chromatin. However, the unknown activity of many other proteins involved in chromatin structure regulation prevents to carry out an unambiguous evaluation of the effect of tested xenobiotics on the studied process. Undoubtedly, we have observed that glyphosate and AMPA affect epigenetic processes that regulate chromatin architecture.
\end{abstract}

Keywords: glyphosate; AMPA; chromatin structure; epigenetics; human peripheral blood mononuclear cells

\section{Introduction}

Glyphosate was discovered to possess herbicidal properties in 1970. Since that time, the use of glyphosate-based herbicides (GBHs) has increased 100-fold [1] with annual application globally in the range of 0.6-1.2 million tons, making GBHs the most widely used herbicides [2,3]. An increasing use of GBHs is mostly attributed to the development of genetically modified crops (GMOs) along with glyphosate's action as a broadspectrum, nonselective herbicide [4,5]. As glyphosate is extensively used in agricultural food production, the human population is exposed both occupationally and environmentally (mainly through the consumption of its residues in food) to its actions.

Aminomethylphosphonic acid (AMPA) is the major product of environmental transformation of glyphosate [6]. Glyphosate and AMPA were selected as priority substances in 
the Human Biomonitoring for Europe initiative [7]. There is insufficient evidence to indicate whether glyphosate is metabolized to AMPA in humans, or whether AMPA present in human samples mainly derives from AMPA residues in cultivated food products [8,9].

Many scientific studies have indicated the presence of glyphosate in the human body. For instance, glyphosate was determined in the blood of people who were not directly exposed to this herbicide $(0.435 \pm 0.167 \mu \mathrm{M})$ [10] and humans occupationally exposed $(0.05-0.5 \mathrm{mM})$ [11], as well as in human urine of the Swedish population of young adults, where the median and maximum concentrations of this herbicide were calculated to be 0.03 , and $3.39 \mu \mathrm{g} / \mathrm{L}$, respectively [12].

Soukup et al. [9] observed (a study conducted in Germany with 301 participants) significant, positive associations between urinary glyphosate excretion and consumption of pulses, or urinary AMPA excretion and mushroom intake. They suggested that despite the widespread use of glyphosate, the exposure of the German population to glyphosate and AMPA was very low. Based on the current risk assessment of glyphosate by European Food Safety Authority (EFSA), such exposure levels are not expected to pose any risk to human health.

Exposure to environmental toxicants can lead to heritable or reversible modifications that can affect gene expression without changing DNA structure, otherwise known as epigenetic changes [13]. The epigenetic processes, include DNA methylation, histone modifications, noncoding RNA regulation, chromatin structure remodeling, and RNA methylation. The knowledge about the ability of glyphosate and other environmental xenobiotics to epigenetic modifications in humans is of great importance.

Recently, Kubsad et al. [14] observed that glyphosate promoted the epigenetic transgenerational inheritance of disease and pathology through germline (i.e., sperm) epimutation in female rats. Negligible pathology was noticed in the F0 and F1 generations, while a significant increase in pathology and disease was noted in the F2 generation grand-offspring and F3 generation great-grand-offspring. Moreover Ben Maamar et al. [15] showed that glyphosate caused the epigenetic transgenerational inheritance of pathology and disease in subsequent great grand offspring (F3 generation) of rats. Those studies have shown that the differential histone retention in sperm appears to have a role in epigenetic transgenerational inheritance.

Recent findings have suggested that glyphosate and AMPA affect changes in the human epigenome, associated with alterations in global methylation [16-19]. Furthermore our previous studies $[20,21]$ had shown that glyphosate and AMPA significantly altered global DNA methylation in peripheral blood mononuclear cells (PBMCs), methylation in the promoter regions of tumor suppressor genes as well as expression of major cell cycle drivers and apoptosis. However, it should be emphasized here that in vitro studies on the effect of glyphosate on PBMCs apoptosis [22] showed that this herbicide only at a very high concentration of $0.5 \mathrm{mM}$ caused apoptotic alterations in the tested cells. Therefore, the above-mentioned result suggests that alterations of DNA methylation patterns do not have to influence specific metabolic effects until exposure to high doses or cumulative long-term exposure of humans to glyphosate.

Chromatin architecture may be affected by various exposures that can directly contact DNA or transcription factors and various binding elements to cause epigenetic changes [23]. The chromatin condensation level can significantly influence the expression of genes and the sensitivity of the DNA to injury. Heterochromatin is resistant to DNA-damaging agents, while euchromatin has increased sensitivity to damage [24,25]. In our previous study [26], glyphosate and AMPA had been shown to induce DNA single strand-breaks (double strand breaks - only glyphosate) and cause purines and pyrimidines oxidation in PBMCs.

Post-translational modifications of both histones within the chromatin and the DNA itself are diverse ways in which the chromatin structure can be remodeled. These modifications are controlled and correspond to various factors, for example, cell cycle. We [20,21] have shown that glyphosate and AMPA changed the methylation pattern of the P16 and TP53 suppressor gene promoters, while glyphosate additionally affected the methylation 
of the $P 21$ protooncogene promoter. Gene profiling showed that glyphosate altered the expression of genes involved in cell cycle regulation: CCND1, P16, and TP53, while AMPA affected the expression only of CCND1.

Because glyphosate and AMPA influenced the above-mentioned factors determining the chromatin state, we decided to determine expression of genes involved in the DNA methylation (DNMT1, DNMT3A) and DNA demethylation process (TET3), as well as chromatin remodeling: analysis of expression of genes involved in the modification of histone methylation (EHMT1, EHMT2) and expression of genes involved in the modification of histone deacetylation (HDAC3, HDAC5).

Specified genes were selected because preliminary reports have shown changes in the expression of these genes in PBMCs and their key role in the establishment of chromatin architecture.

The human cells were incubated with glyphosate in concentrations ranging from 0.5 to $100 \mu \mathrm{M}$ and with AMPA in concentrations ranging from 0.5 to $250 \mu \mathrm{M}$, which did not induce cytotoxic effects on PBMCs viability.

\section{Results}

2.1. Analysis of Expression of Genes Involved in the DNA Methylation (DNMT1, DNMT3A) and DNA Demethylation Process (TET3)

We found a statistically significant ( $p<0.05$, one-way ANOVA) increase of DNMT1 expression in PBMCs treated with all concentrations of glyphosate and two concentrations of AMPA $(10 \mu \mathrm{M}$ and $250 \mu \mathrm{M})$ for $24 \mathrm{~h}$ (Figure 1A).

Glyphosate induced a significant increase in DNMT3A expression only at its highest concentration of $100 \mu \mathrm{M}(p<0.05$, one-way ANOVA). We did not observe statistically significant changes in DNMT3A expression in PMBCs treated with AMPA (Figure 1B).

Treatment of PBMCs with glyphosate and AMPA did not affect the expression of TET3 (Figure 1C).

2.2. Analysis of the Expression of Genes Involved in the Modification of Histone Methylation (EHMT1, EHMT)

We did not observe any statistically significant changes in EHMT1 and EHMT2 expression in PBMCs treated for $24 \mathrm{~h}$ with glyphosate and AMPA ( $p>0.05$, one-way ANOVA) (Figure 2A,B). However, after 24-h treatment of PBMCs with glyphosate, an upward trend in the expression of EHMT1 was noticed (Figure 2A). Similarly, incubation of the cells with AMPA showed an upward trend in the expression of EHMT2 (Figure 2B). 
A

DNMT1

DNMT1
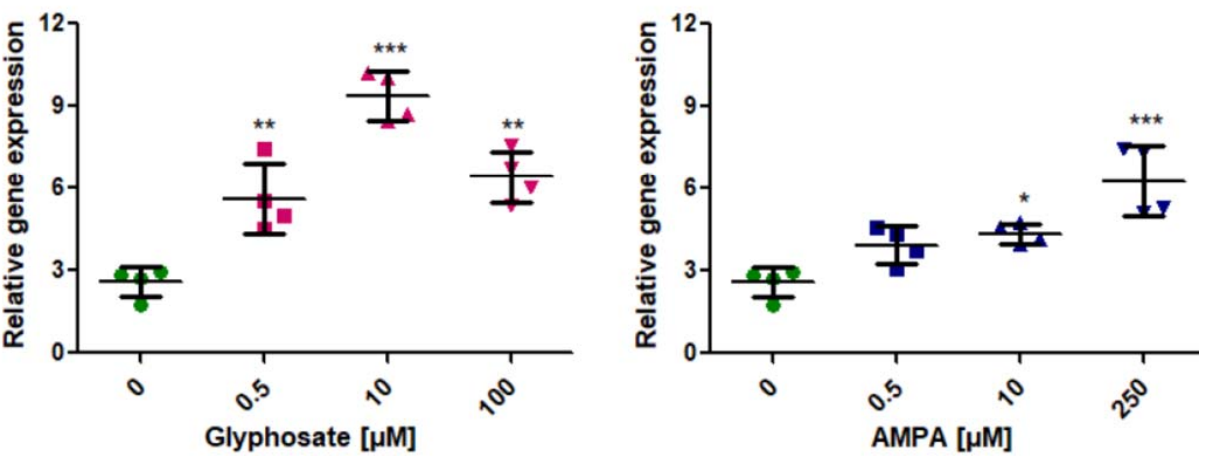

B

DNMT3A

DNMT3A

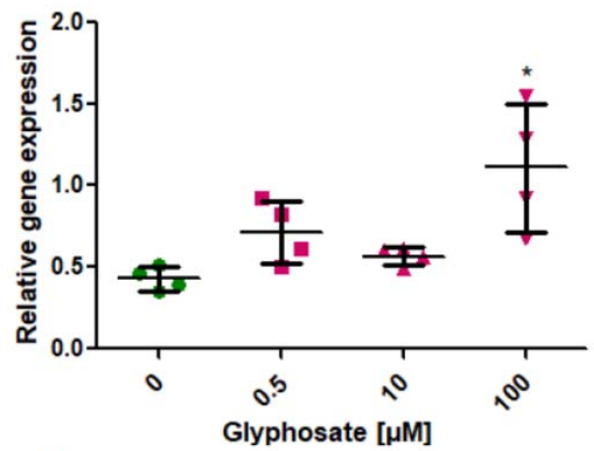

C

TET3

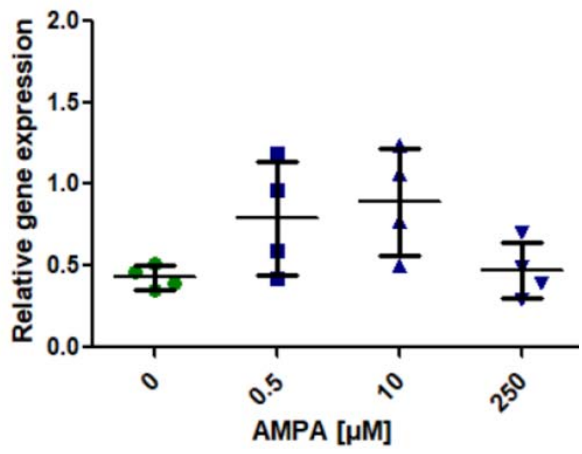

TET3
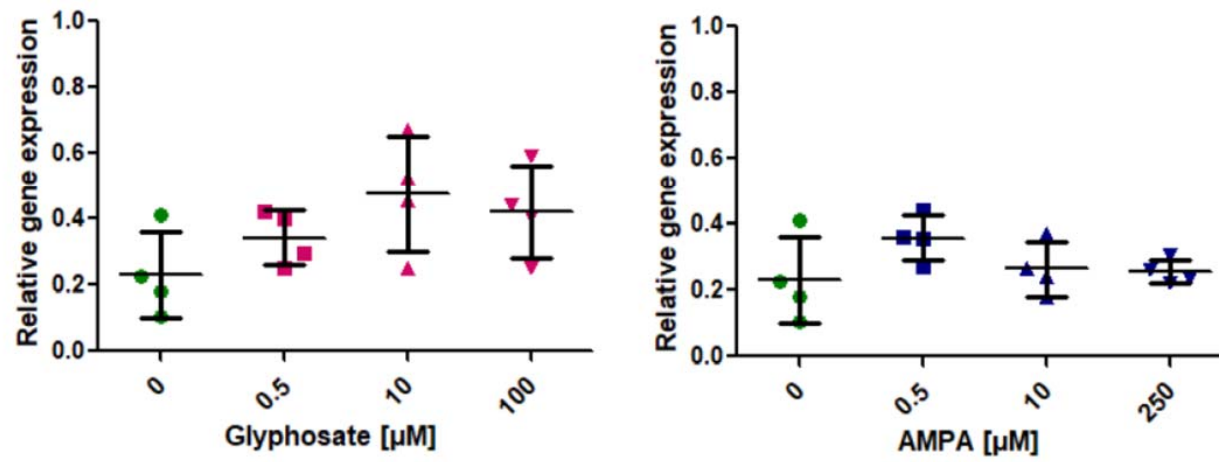

Figure 1. Expression of genes involved in DNA methylation-DNMT1 (A), DNMT3A (B), and DNA demethylation-TET3 $(\mathbf{C})$ process in human PBMCs incubated with glyphosate $(0.5-100 \mu \mathrm{M})$ and AMPA $(0.5-250 \mu \mathrm{M})$ for $24 \mathrm{~h}$. Mean \pm SD was calculated for four individual experiments (four blood donors). Statistically different from control at ${ }^{*} p<0.05 ;{ }^{* *} p<0.01$ and ${ }^{* * *} p<0.001$. Statistical analysis was conducted using one-way ANOVA and a posteriori Tukey test. 
A

EHMT1

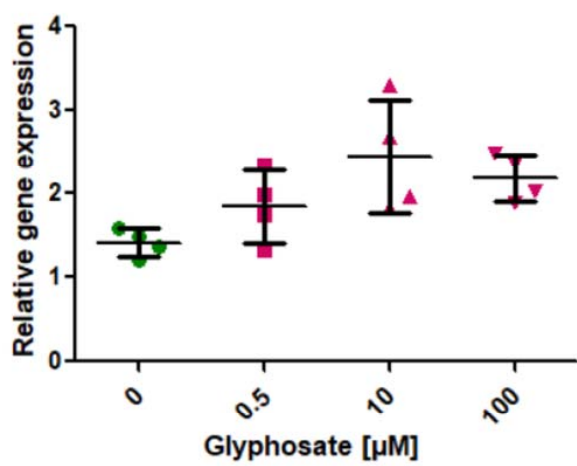

B

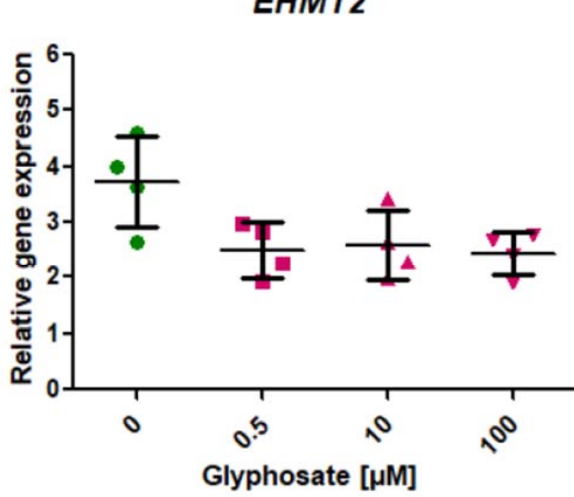

EHMT1

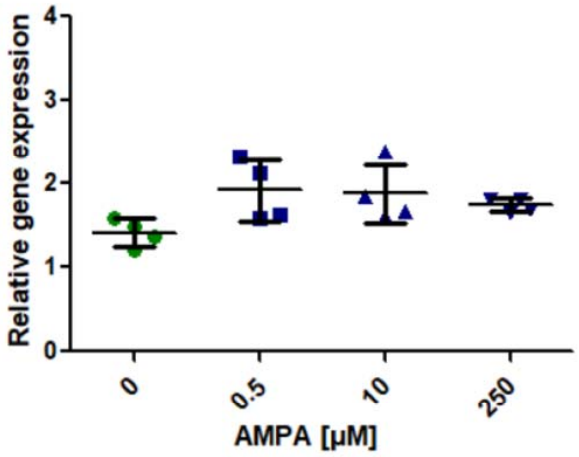

EHMT2

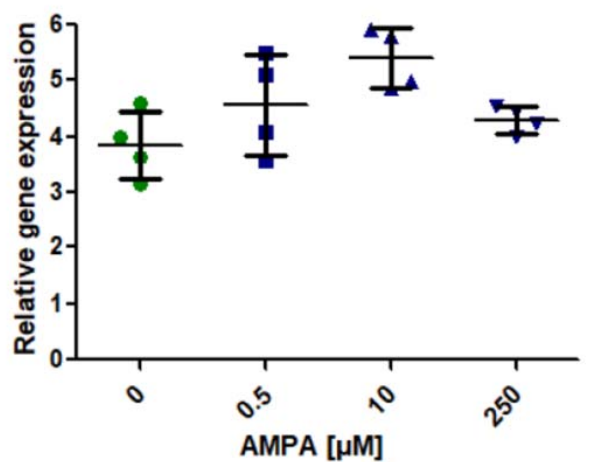

Figure 2. Expression of genes involved in histone methylation-EHMT1 (A), EHMT2 (B) in human PBMCs incubated with glyphosate $(0.5-100 \mu \mathrm{M})$ and AMPA $(0.5-250 \mu \mathrm{M})$ for $24 \mathrm{~h}$. Mean \pm SD was calculated for four individual experiments (four blood donors). Statistical analysis was conducted using one-way ANOVA.

2.3. Analysis of Expression of Genes Involved in the Modification of Histone Deacetylation (HDAC3, HDAC5) (HDAC3, HDAC5)

We found a statistically significant ( $p<0.05$, one-way ANOVA) increase of HDAC3 expression in PBMCs treated with glyphosate from its lowest concentration of $0.5 \mu \mathrm{M}$ for $24 \mathrm{~h}$ (Figure 3A). AMPA induced a significant increase in HDAC3 expression only at its highest concentration of $250 \mu \mathrm{M}$ ( $p<0.05$, one-way ANOVA) (Figure 3A). 

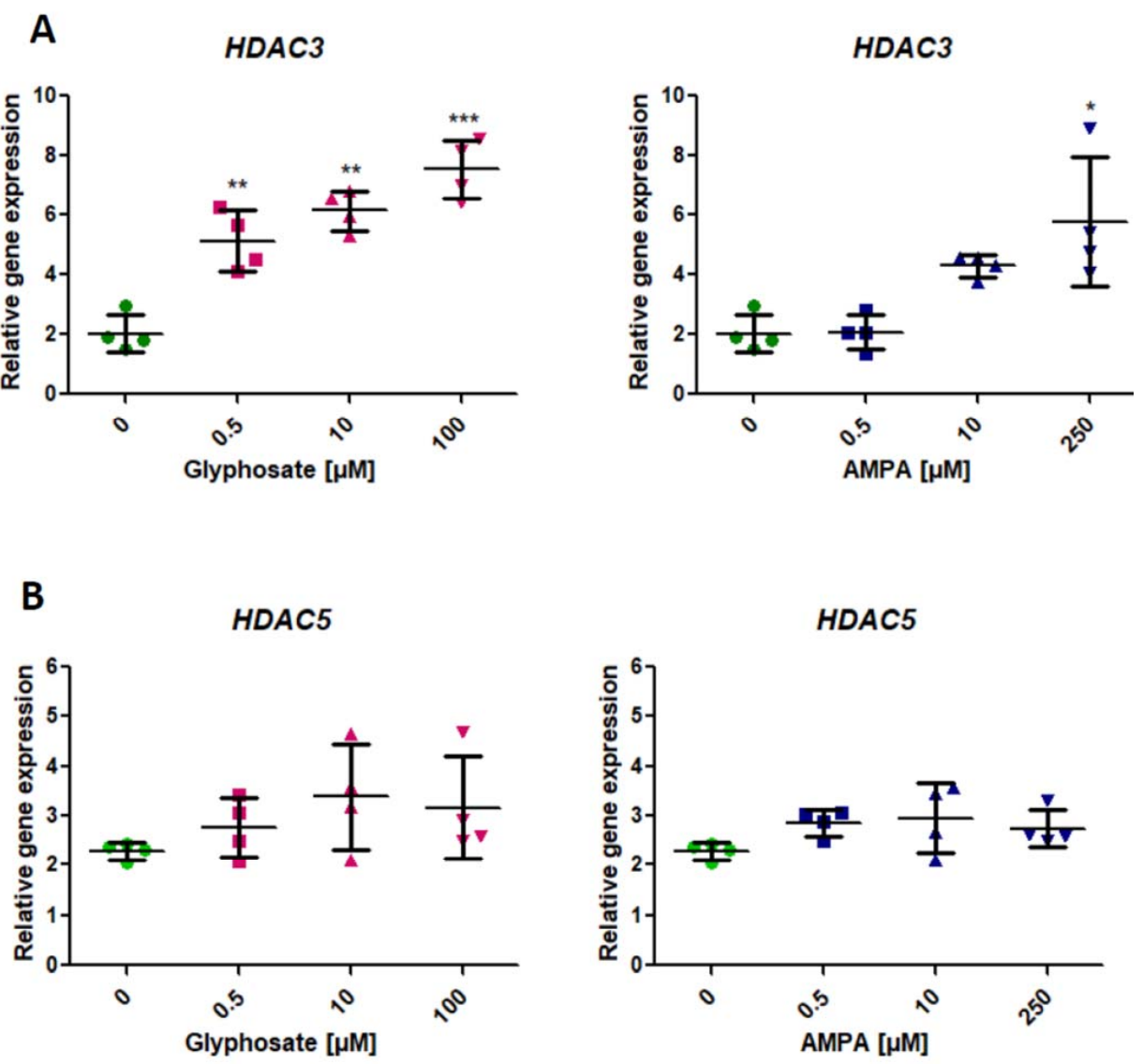

Figure 3. Expression of genes involved in the histone deacetylation-HDAC3 (A) and HDAC5 (B) in human PBMCs incubated with glyphosate $(0.5-100 \mu \mathrm{M})$ and AMPA $(0.5-250 \mu \mathrm{M})$ for $24 \mathrm{~h}$. Mean \pm $\mathrm{SD}$ was calculated for four individual experiments (four blood donors). Statistically different from control at ${ }^{*} p<0.05 ;{ }^{* *} p<0.01$ and ${ }^{* * *} p<0.001$. Statistical analysis was conducted using one-way ANOVA and a posteriori Tukey test.

We did not observe any statistically significant changes in HDAC5 expression in PMBCs treated with the tested xenobiotics (Figure 3B).

\section{Discussion}

In this study, for the first time, we investigated the indirect effect of glyphosate and its metabolite-aminomethylphosphonic acid (AMPA) on epigenetic modifications associated with the regulation of chromatin structure, through the analysis of the expression patterns of genes involved in DNA and histone regulation in PBMCs in vitro model.

Chromatin condensation and decondensation is a complex process that depends on many factors, including various protein complexes, histone variants, and biochemical modifications. DNA methylation is regulated by a number of enzymes, including DNA methyltransferase (DNMT) and histone deacetylase (HDAC). DNMT1 works as a maintenance methyltransferase, preferably methylating the fifth position of the cytosine residues), ensuring the same methylation pattern during DNA replication and cell division, while DNMT3A enzymes, known as de novo methyltransferases, work to establish new methylation patterns of hypomethylated DNA necessary for tissue-specific differentiation during development [27-29]. In silico evaluation of pesticide action as potential modulators of human DNA methyltransferases, showed that rodenticides (flocoumafen, brodifacoum, difenacoum) are potential DNMT (for both DNMT1 and DNMT3A) ligands, and therefore, may modulate DNA methylations [30]. It must, however, be kept in mind that rodenticides have a different mechanism of action than glyphosate and AMPA. 
We have found an increased DNMT1 expression in response to treatment of PBMCs with glyphosate at all its concentrations and AMPA at $10 \mu \mathrm{M}$ and $250 \mu \mathrm{M}$. Further analysis of enzymes, known as de novo methyltransferases revealed an increased expression of the DNMT3A gene in glyphosate-treated tested cells $(100 \mu \mathrm{M})$. Our analyses have not shown any changes in DNMT3A expression in PBMCs incubated with AMPA. Just recently, changes in the DNA methylation machinery due to glyphosate exposure were identified in the fish model of Japanese medaka (Oryzias latipes), where upregulation of Dnmt1, Dnmt3a gene expression was shown [31]. In addition other pesticides (with different mechanism of action than glyphosate) extensively used around the world, revealing similar effects. For instance, treatment of the human breast cancer cell line, MCF-7 for $12 \mathrm{~h}$ and $24 \mathrm{~h}$ with endosulfan at $10 \mu \mathrm{M}$ led to significant upregulation of both DNMT1 and de novo DNMT3A and DNMT3B. Moreover, the total intracellular histone deacetylase (HDAC) activity was found to be significantly increased, which was correlated with the upregulation of class I HDACs (HDAC 1 and HDAC3), while no significant alteration in the other HDAC classes was observed in MCF-7 cells [32].

Our analysis of the expression of histone deacetylases revealed an increased expression of HDAC3 in PBMCs exposed to glyphosate at its all tested concentrations $(0.5-100 \mu \mathrm{M})$ and AMPA at its highest concentration of $250 \mu \mathrm{M}$. However, no statistically significant changes in the expression level of HDAC5 have been noted.

Chromatin plays an essential role in the activation and inhibition of gene transcription by regulating the availability of transcription factor (TF) binding. Increased DNMT1 and $H D A C 3$ activity contributes to the condensation of chromatin, preventing TF attachment, resulting in inhibition of transcription. It has been documented that such a phenomenon accompanies the process of neoplastic transformation and relates primarily to silencing suppressor gene expression [33-38].

We have observed that glyphosate and AMPA increased expression of DNMT1 and HDAC3 genes. Consequently, it can lead to high activity of DNMT1 and HDAC3 and finally to chromatin condensation, which prevents TFs binding and inhibition of transcription (Figure 4).

Ten-eleven translocations (TET) are other enzymes active in DNA methylation, which oxidize 5-methylcytosine (5-mC) to 5-hydroxymethylcytosine (5-hmC), leading to DNA demethylation by removing 5-mC from the genome [39-41]. Duforestel et al. [17] used nonneoplastic MCF10A cells in a repeated glyphosate exposure pattern over 21 days. They observed that glyphosate triggered a significant increase in the activity of ten-eleven translocation (TET3) enzyme and could affect breast cells to tumorigenesis via epigenetic reprogramming, which occurred through TET3-mediated global and local DNA hypomethylation. In the aforementioned studies on the fish model of Japanese medaka (Oryzias latipes), glyphosate also caused upregulation of Tet1 and Tet3 gene expression [31]. Similar results were obtained in the rodent model. A two-year study on rats given $0.1 \mathrm{ppb}$ of Roundup (50 ng/L of glyphosate equivalent) via drinking water (daily intake of $4 \mathrm{ng} / \mathrm{kg}$ bw/day of glyphosate) was conducted and showed an increased expression of Dnmt3a and Tet3 gene [42] Nevertheless, our analysis has not revealed any changes in the expression level of TET3 gene in human PBMCs incubated with glyphosate or AMPA.

To date, there is no information regarding the effect of glyphosate on histone modification in human cells. The only previously mentioned study by Mesnage et al. [42] showed the effect of glyphosate on the genes responsible for regulating the structure of chromatin (Men1, Setdb1, Suv420h2, Dot1l, Ehmt1, Ehmt2, Nsd1). However, we have not observed any statistically significant changes in EHMT1 and EHMT2 gene expression, in human PBMCs incubated with tested xenobiotics. 


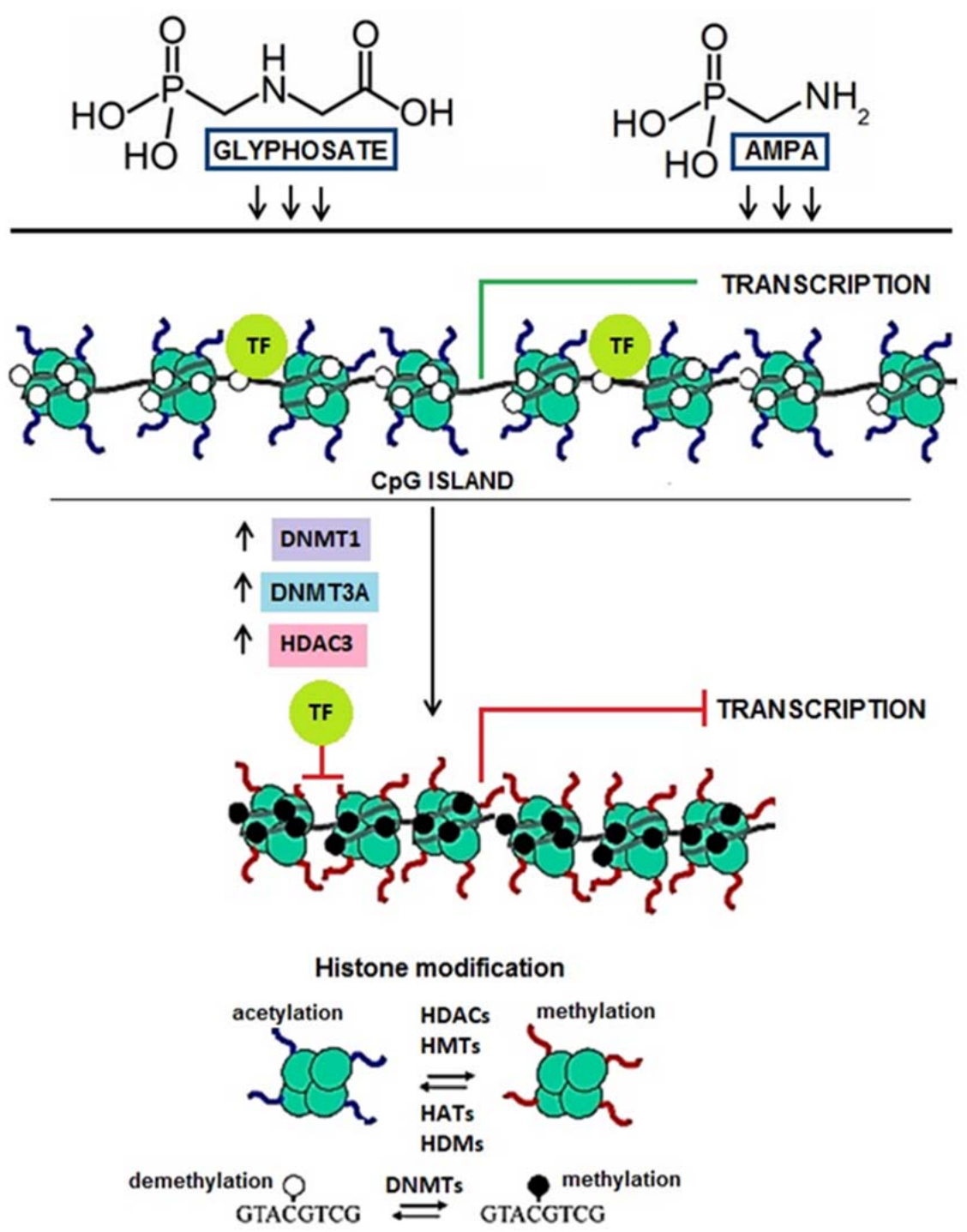

Figure 4. The potential impact of glyphosate and AMPA on chromatin structure. Chromatin plays a crucial role in gene activation and inhibition by regulating the accessibility of transcription factor (TG) binding. Methyl groups are coupled to cytosines by the family of DNA methyltransferases (DNMTs), where DNMT1 is the main maintenance enzyme and the DNMT3A branch of the family is mostly responsible for de novo methylation.

The main limitation of our work is the lack of measurement of histone acetylation levels upon glyphosate/AMPA treatment. The results would be significantly strengthened if the biological effect of the increase of HDAC3 in PBMCs on histone acetylation could be assessed. Additionally, the information about the potential influence of glyphosate on the activity of the enzymes (rather than their expression) would be important. These studies would show a measurable, potential biological effect of changes in the expression of the studied genes.

\section{Materials and Methods}

\subsection{Chemicals}

$N$-(phosphonomethyl)glycine (glyphosate) (purity 95\%), fetal bovine serum (FBS), penicillin/streptomycin, TRIzolTM and primers were bought from Sigma-Aldrich ${ }^{\circledR},($ Darmstadt, Germany). Aminomethylphosphonic acid (AMPA) (purity 98\%) were synthetized by the Institute of Industrial Organic Chemistry, Łukasiewicz Research Network, Warsaw, Poland. 
RPMI 1640 medium with L-glutamine and lymphocyte separation medium (LSM) $\left(1.077 \mathrm{~g} / \mathrm{cm}^{3}\right)$ were purchased from Cytogen (Greven, Germany). Transcriptor First Strand cDNA Synthesis Kit and FastStart Essential DNA Green Master were purchased from Roche (Basel, Switzerland). TRIzolTM Reagent was bought from Thermo Fischer Scientific, Waltham, MA, USA. Other chemicals were from Carl Roth (Karlsruhe, Germany) and POCh (Gliwice, Poland) and were of analytical grade.

\subsection{Cells Isolation}

PBMCs were isolated from a leucocyte-buffy coats obtained from blood purchased in Blood Bank in Lodz, Poland. Blood was obtained from four healthy volunteers (aged 18-55), who showed no signs of infection symptoms at the time the blood samples were collected. The investigation was approved by the Bioethics Committee of the University of Lodz No. 1/KBBN-UŁ/II/2017.

Cell isolation was conducted according to the procedure described by Woźniak et al. [26]. The final PBMCs density used in the experiments (after addition of glyphosate) was $1 \times 10^{6}$ cells $/ \mathrm{mL}$.

\subsection{Cells Treatment}

Glyphosate and AMPA were dissolved in PBS, $\mathrm{pH}$ 7.4. The cells were incubated with glyphosate at final concentrations of $0.5 ; 10 ; 100 \mu \mathrm{M}$ and with AMPA at finally concentrations of $0.5 ; 10 ; 250 \mu \mathrm{M}$ for $24 \mathrm{~h}$ in four independent experiments on blood samples collected from four donors. PBS (in which xenobiotics were dissolved) was added to the control samples. Cells suspension from individual donor $(396 \mu \mathrm{L})$ was incubated with $4 \mu \mathrm{l}$ of PBS (control sample), $4 \mu \mathrm{L}$ of glyphosate or $4 \mu \mathrm{L}$ of AMPA (blood samples from four donors were used for all control or glyphosate/AMPA treatments).

The concentrations of glyphosate and AMPA used in this study corresponded to their levels determined in humans environmentally exposed. No statistically significant change in cell viability were observed as a result of PBMCs treatment with glyphosate or AMPA at selected (above mentioned) concentrations as previously presented by Woźniak et al. [26]. Obligatory, in each series of probes, the viability of the tested cells was determined by Trypan Blue dye exclusion test.

During incubation, the cells were resuspended in RPMI supplemented with $10 \%$ FBS and penicillin/streptomycin solution $(50 \mathrm{U} / \mathrm{mL})$ at $37{ }^{\circ} \mathrm{C}$ and $5 \% \mathrm{CO}_{2}$. After incubation, the cells were centrifuged, the tested compounds were discarded, and the cells were resuspended in RPMI medium.

\subsection{Gene Expression}

RNA was extracted with TRIzolTM. RNA samples with a $260 / 280 \mathrm{~nm}$ ratio in the range of 1.8-2.0 were used for further analysis. The isolated RNA was reversely transcribed (Transcriptor First Strand cDNA Synthesis Kit, Roche), and cDNA was quantified by real-time PCR (FastStart SYBR Green Master, Roche, Basel, Switzerland).

$G A P D H, R P L 13, R P L P 0$ were used as reference genes, verified for PMBCs. Primers listed in Table 1 were designed by means of Primer-BLAST NCBI-NIH website: https: / / www.ncbi.nlm.nih.gov/tools/primer-blast/ (accessed on 1 February 2020). The $2^{-\Delta \mathrm{Ct}}$ method was used to calculate the expression levels of the studied genes and expressed as relative copy number values [43]. 
Table 1. The primers' sequences used in the Real-Time PCR.

\begin{tabular}{|c|c|c|c|}
\hline Gene & Primer & Nucleotide Sequence $5^{\prime}-3^{\prime}$ & $\begin{array}{c}\text { PCR } \\
\text { Product }[b p]\end{array}$ \\
\hline DNMT1 & $\begin{array}{l}\text { forward } \\
\text { reverse }\end{array}$ & $\begin{array}{l}\text { GTGGAAGCCGGCAAAGC } \\
\text { TCCCACTCGAGCCTTCCATA }\end{array}$ & 125 \\
\hline DNMT3A & $\begin{array}{l}\text { forward } \\
\text { reverse }\end{array}$ & $\begin{array}{l}\text { AAGGAGGAGCGCCAAGAG } \\
\text { ATCACCGCAGGGTCCTTT }\end{array}$ & 113 \\
\hline EHMT1 & $\begin{array}{l}\text { forward } \\
\text { reverse }\end{array}$ & $\begin{array}{l}\text { CCTCGACTCGGAAAAACCCAA } \\
\text { AGAGCGCTTATTCTGGTGCT }\end{array}$ & 148 \\
\hline EHMT2 & $\begin{array}{l}\text { forward } \\
\text { reverse }\end{array}$ & $\begin{array}{l}\text { CATCGATCGCAACATCACCC } \\
\text { GAGCAATCGCCCATCCTTGT }\end{array}$ & 121 \\
\hline HDAC3 & $\begin{array}{l}\text { forward } \\
\text { reverse }\end{array}$ & $\begin{array}{l}\text { TGACTCTCTGGGCTGTGATCG } \\
\text { CATATTCAACGCATTCCCAATGC }\end{array}$ & 74 \\
\hline HDAC5 & $\begin{array}{l}\text { forward } \\
\text { reverse }\end{array}$ & $\begin{array}{l}\text { CTTAGCAAGTGCGAGCGGAT } \\
\text { TGTCTAGCTTCTGCCGGTTG }\end{array}$ & 121 \\
\hline TET3 & $\begin{array}{l}\text { forward } \\
\text { reverse }\end{array}$ & $\begin{array}{l}\text { CACTAGCTGTACCAACCGCC } \\
\text { CAGCCTTTATTTCCACCTCCTTGA }\end{array}$ & 104 \\
\hline \multicolumn{4}{|c|}{ House keeping genes } \\
\hline GAPDH & $\begin{array}{l}\text { forward } \\
\text { reverse }\end{array}$ & $\begin{array}{l}\text { AGCCACATCGCTCAGACAC } \\
\text { GCCCAATACGACCAAATCC }\end{array}$ & 66 \\
\hline RPLO & $\begin{array}{l}\text { forward } \\
\text { reverse }\end{array}$ & $\begin{array}{l}\text { TCTACAACCCTGAAGTGCTTGAT } \\
\text { CAATCTGCAGACAGACACTGG }\end{array}$ & 96 \\
\hline RPL13 & $\begin{array}{l}\text { forward } \\
\text { reverse }\end{array}$ & $\begin{array}{l}\text { CAAGCGGATGAACACCAAC } \\
\text { TGTGGGGCAGCATACCTC }\end{array}$ & 95 \\
\hline
\end{tabular}

\subsection{Statistical Analysis}

Statistical analysis was performed with STATISTICA 13.1 data analysis software (2000 Stat-Soft, Inc., Tulsa, OK, USA). We checked a normality of relative expression distribution using Shapiro-Wilk test as well as the homogeneity of variance by Brown-Fisher test. Statistical analysis was conducted using one-way analysis of variance (ANOVA) followed by Tukey's post hoc multiple comparison procedure. The difference was considered significant for $p<0.05$. The individual analysis was performed on blood from four donors, while a single experiment conducted on blood from one donor was repeated twice or thrice depending on the method used.

\section{Conclusions}

Summing up, in this study, gene profiling have shown that glyphosate upregulated the expression of genes involved in the DNA methylation process, i.e., DNMT1 and DMNT3A as well as HDAC3 genes involved in the deacetylation of histone proteins, while AMPA altered the expression of DNMT1 and HDAC3. It must be noted that glyphosate at lower concentrations than AMPA caused changes in the expression of these genes.

Our results have revealed a potential change in gene expression in human PBMCs exposed to glyphosate and AMPA, but the observed alterations do not prejudge the final regulation of chromatin structure, which is depended on many other factors. More studies are required, including those based on long-term exposure models, to provide deeper insights into the epigenetic effect of glyphosate and its further implications at the cellular level.

Author Contributions: E.W. planned and performed the experiments; E.W. and E.J. evaluated the data and wrote the manuscript; E.R. and B.B. supervised the project and wrote the manuscript; J.M. wrote the manuscript and proofread the paper; B.H. synthesized AMPA. All authors have read and agreed to the published version of the manuscript.

Funding: This work was financed by a statutory research admitted by Department of Biophysics of Environmental Pollution, University of Lodz (number B16/17 000000191.01) and Polish Ministry of Science and Higher Education (number B1811000001802.02).

Institutional Review Board Statement: The investigation was approved by the Bioethics Committee of the University of Lodz No. 1/KBBN-UŁ/II/2017. 
Informed Consent Statement: Leukocyte-buffy coat was purchased from Blood Bank in Lodz, Poland. All procedures related to blood donation were executed at the Regional Centre of Blood Donation and Blood Treatment in Lodz, Poland. The blood donor recruitment was at the Centre, according to national legal procedures and European Union regulations (incl. the regulation (EU) 2016/679 of the European Parliament and of the Council of 27 April 2016 on the protection of natural persons regarding the processing of personal data and on the free movement of such data).

Data Availability Statement: Not applicable.

Conflicts of Interest: The authors declare no conflict of interest.

$\begin{array}{ll}\text { Abbreviations } \\ \text { AMPA } & \text { Aminomethylphosphonic acid } \\ \text { DNMT1 } & \text { DNA methyltransferase } \\ \text { DNMT3A } & \text { DNA methyltransferase 3 alpha } \\ \text { ECHA } & \text { European Chemicals Agency } \\ \text { EFSA } & \text { European Food Safety Authority } \\ \text { EHMT1 } & \text { Euchromatic histone lysine methyltransferase 1 } \\ \text { EHMT2 } & \text { Euchromatic histone lysine methyltransferase 2 } \\ \text { GMOs } & \text { Genetically modified crops } \\ \text { GBHs } & \text { Glyphosate-based herbicides (GBHs) } \\ \text { HBM4EU } & \text { Human Biomonitoring for Europe initiative } \\ \text { HDAC3 } & \text { Histone deacetylase 3 } \\ \text { HDAC5 } & \text { Histone deacetylase 5 } \\ \text { IARC } & \text { International Agency for Research on Cancer } \\ \text { PMBCs } & \text { Human peripheral blood mononuclear cells } \\ \text { TET1 } & \text { Tet methylcytosine dioxygenase 1 } \\ \text { TET3 } & \text { Tet methylcytosine dioxygenase 3 } \\ \text { TF } & \text { Transcription factor binding } \\ \text { US EPA } & \text { United State Environmental Protection Agency } \\ \text { WHO } & \text { World Human Organization }\end{array}$

\section{References}

1. Zhang, L.; Rana, J.; Shaffer, R.M.; Taioli, E.; Sheppard, L. Exposure to glyphosate-based herbicides and risk for non-Hodgkin lymphoma: A meta-analysis and supporting evidence. Mutat. Res. 2019, 781, 186-206. [CrossRef] [PubMed]

2. $\quad$ Rodrigues, B.L.; de Oliveira, R.; Abe, F.R.; Brito, L.B.; Moura, D.S.; Valadares, M.C.; Grisolia, C.K.; de Oliveira, D.P.; de Oliveira, G.A.R. Ecotoxicological assessment of glyphosate-based herbicides: Effects on different organisms. Environ. Toxicol. Chem. 2017, 36, 1755-1763. [CrossRef] [PubMed]

3. Mesnage, R.; Defarge, N.; de Vendômois, J.S.; Séralini, G.E. Potential toxic effects of glyphosate and its commercial formulations below regulatory limits. Food Chem. Toxicol. 2015, 84, 133-153. [CrossRef]

4. Roy, N.M.; Carneiro, B.; Ochs, J. Glyphosate induces neurotoxicity in zebrafish. Environ. Toxicol. Pharmacol. 2016, 42, 45-54. [CrossRef]

5. Myers, J.P.; Antoniou, M.N.; Blumberg, B.; Carroll, L.; Colborn, T.; Everett, L.G.; Hansen, M.; Landrigan, P.J.; Lanphear, B.P.; Mesnage, R.; et al. Concerns over use of glyphosate-based herbicides and risks associated with exposures: A consensus statement. Environ. Health 2016, 15, 19. [CrossRef]

6. Benbrook, C.M. Trends in glyphosate herbicide use in the United States and globally. Environ. Sci. Eur. 2016, 28, 3. [CrossRef]

7. HBM4EU Priority Substances. Available online: https://www.hbm4eu.eu/the-substances/ (accessed on 10 February 2021).

8. Connolly, A.; Coggins, M.A.; Koch, H.M. Human biomonitoring of glyphosate exposures: State-of-the-art and future research challenges. Toxics 2020, 18, 60. [CrossRef]

9. Soukup, S.T.; Merz, B.; Bub, A.; Hoffman, I.; Watzl, B.; Steinberg, P.; Kulling, S.E. Glyphosate and AMPA levels in human urine samples and their correlation with food consumption: Results of the cross-sectional KarMeN study in Germany. Arch. Toxicol. 2020, 94, 1575-1584. [CrossRef]

10. Aris, A.; Leblanc, S. Maternal and fetal exposure to pesticides associated to genetically modified foods in eastern townships of Quebec, Canada. Reprod. Toxicol. 2011, 31, 528-533. [CrossRef]

11. Zouaoui, K.; Dulaurent, S.; Gaulier, J.M.; Moesch, C.; Lachâtre, G. Determination of glyphosate and AMPA in blood and urine from humans: About 13 cases of acute intoxication. Forensic Sci. Int. 2013, 226, 20-25. [CrossRef] [PubMed]

12. Faniband, M.H.; Norén, E.; Littorin, M.; Lindh, C.H. Human experimental exposure to glyphosate and biomonitoring of young Swedish adults. Int. J. Hyg. Environ. Health 2021, 231, 113657. [CrossRef] [PubMed] 
13. Patkin, E.L.; Sofronov, H.A. Population epigenetics, ecotoxicology and human diseases. Rus. J. Genet. App. Res. 2012, 10, 14-28. [CrossRef]

14. Kubsad, D.; Nilsson, E.E.; King, S.E.; Sadler-Riggleman, I.; Beck, D.; Skinner, M.K. Assessment of Glyphosate Induced Epigenetic Transgenerational Inheritance of Pathologies and Sperm Epimutations: Generational Toxicology. Sci. Rep. 2019, 9, 6372. [CrossRef]

15. Ben Maamar, M.; Beck, D.; Nilsson, E.E.; Kubsad, D.; Skinner, M.K. Epigenome-wide association study for glyphosate induced transgenerational sperm DNA methylation and histone retention epigenetic biomarkers for disease. Epigenetics 2020, 9, 1-18. [CrossRef] [PubMed]

16. Benedetti, D.; Lopes Alderete, B.; de Souza, C.T.; Ferraz Dias, J.; Niekraszewicz, L.; Cappetta, M.; Martínez-López, W.; Da Silva, J. DNA damage and epigenetic alteration in soybean farmers exposed to complex mixture of pesticides. Mutagenesis 2018, 33, 87-95. [CrossRef] [PubMed]

17. Duforestel, M.; Nadaradjane, A.; Bougras-Cartron, G.; Briand, J.; Olivier, C.; Frenel, J.S.; Vallette, F.; Lelièvre, S.; Cartron, P.F. Glyphosate Primes Mammary Cells for Tumorigenesis by Reprogramming the Epigenomeina TET3-Dependent Manner. Front. Genet. 2019, 10, 885. [CrossRef] [PubMed]

18. Kahl, V.F.S.; Dhillon, V.; Fenech, M.; de Souza, M.R.; da Silva, F.N.; Marroni, N.A.P.; Nunes, E.A.; Cerchiaro, G.; Pedron, T.; Batista, B.L.; et al. Occupational Exposure to Pesticides in Tobacco Fields: The Integrated Evaluation of Nutritional Intake and Susceptibility on Genomic and Epigenetic Instability. Oxid. Med. Cell Longev. 2018, 2018, 7017423. [CrossRef] [PubMed]

19. Kwiatkowska, M.; Reszka, E.; Woźniak, K.; Jabłońska, E.; Michałowicz, J.; Bukowska, B. DNA damage and methylation induced by glyphosate in human peripheral blood mononuclear cells (in vitro study). Food Chem. Toxicol. 2017, 105, 93-98. [CrossRef]

20. Woźniak, E.; Reszka, E.; Jabłońska, E.; Balcerczyk, A.; Broncel, M.; Bukowska, B. Glyphosate affects methylation in the promoter regions of selected tumor suppressors as well as expression of major cell cycle and apoptosis drivers in PBMCs (in vitro study). Toxicol. Vitro 2020, 63, 104736. [CrossRef]

21. Woźniak, E.; Reszka, E.; Jabłońska, E.; Mokra, K.; Balcerczyk, A.; Huras, B.; Zakrzewski, J.; Bukowska, B. The selected epigenetic effects of aminomethylphosphonic acid, a primary metabolite of glyphosate on human peripheral blood mononuclear cells (in vitro). Toxicol. Vitro 2020, 30, 104878. [CrossRef]

22. Kwiatkowska, M.; Michałowicz, J.; Jarosiewicz, P.; Pingot, D.; Sicińska, P.; Huras, B.; Zakrzewski, J.; Jarosiewicz, M.; Bukowska, B. Evaluation of apoptotic potential of glyphosate metabolites and impurities in human peripheral blood mononuclear cells (in vitro study). Food Chem. Toxicol. 2020, 135, 110888. [CrossRef]

23. Marsit, C.J. Influence of environmental exposure on human epigenetic regulation. J. Exp. Biol. 2015, 1, 71-79. [CrossRef]

24. Nair, N.; Shoaib, M.; Sorenson, C.S. Chromatin Dynamics in Genome Stability: Roles in Suppressing Endogenous DNA Dam-age and Facilitating DNA Repair. Int. J. Mol. Sci. 2017, 18, 1486. [CrossRef]

25. Takata, H.; Hanafusa, T.; Mori, T.; Shimura, M.; Iida, Y.; Ishikawa, K.; Yoshikawa, K.; Yoshikawa, Y.; Maeshima, K. Chromatin Compaction Protects Genomic DNA from Radiation Damage. PLoS ONE 2013, 8, e75622. [CrossRef]

26. Woźniak, E.; Sicińska, P.; Michałowicz, J.; Woźniak, K.; Reszka, E.; Huras, B.; Zakrzewski, J.; Bukowska, B. The mechanism of DNA damage induced by Roundup 360 PLUS, glyphosate and AMPA in human peripheral blood mononuclear cells-Genotoxic risk assessement. Food Chem. Toxicol. 2018, 120, 510-522. [CrossRef]

27. Kim, M.; Costello, J. DNA methylation: An epigenetic mark of cellular memory. Exp. Mol. Med. 2017, 49, e322. [CrossRef] [PubMed]

28. Zhou, Y.; Liu, S.; Hu, Y.; Fang, L.; Gao, Y.; Xia, H.; Schroeder, S.G.; Rosen, B.D.; Connor, E.E.; Li, C.; et al. Comparative whole genome DNA methylation profiling across cattle tissues reveals global and tissue-specific methylation patterns. BMC Biol. 2020, 18, 85. [CrossRef] [PubMed]

29. Ehrlich, M. DNA hypermethylation in disease: Mechanisms and clinical relevance. Epigenetics 2019, 14, 1141-1163. [CrossRef] [PubMed]

30. Coronado-Posada, N.; Olivero-Verbel, J. In silico evaluation of pesticides as potential modulators of human DNA methyltransferases. SAR QSAR Environ. Res. 2019, 30, 865-878. [CrossRef]

31. Smith, C.M.; Vera, M.K.M.; Bhandari, R.K. Developmental and epigenetic effects of Roundup and glyphosate exposure on Japanese medaka (Oryzias latipes). Aquat. Toxicol. 2019, 210, 215-226. [CrossRef]

32. Ghosh, K.; Chatterjee, B.; Jayaprasad, A.G.; Kanade, S.R. The persistent organochlorine pesticide endosulfan modulates multiple epigenetic regulators with oncogenic potential in MCF-7 cells. Sci. Total Environ. 2018, 15, 1612-1622. [CrossRef]

33. Cheng, Y.; He, C.; Wang, M.; Ma, X.; Mo, F.; Yang, S.; Han, J.; Wei, X. Targeting epigenetic regulators for cancer therapy: Mechanisms and advances in clinical trials. Signal Transduct. Target. Ther. 2019, 4, 62. [CrossRef] [PubMed]

34. Piyathilake, C.J.; Badiga, S.; Borak, S.G.; Weragoda, J.; Bae, S.; Matthews, R.; Bell, W.C.; Partridge, E.E. A higher degree of expression of DNA methyl transferase 1 in cervical cancer is associated with poor survival outcome. Int. J. Women's Health 2017, 9, 413-420. [CrossRef]

35. Miao, L.J.; Huang, F.X.; Sun, Z.T.; Zhang, R.X.; Huang, S.F.; Wang, J. Stat3 inhibits Beclin 1 expression through recruitment of HDAC3 in nonsmall cell lung cancer cells. Tumor Biol. 2014, 35, 7097-7103. [CrossRef]

36. Chen, G.; Gu, Y.; Han, P.; Li, Z.; Zhao, J.L.; Gao, M.Z. Long noncoding RNA SBF2-AS1 promotes colorectal cancer proliferation and invasion by inhibiting miR-619-5p activity and facilitating HDAC3 expression. J. Cell Physiol. 2019, 234, 18688-18696. [CrossRef] [PubMed] 
37. Bayat, S.; Derakhshan, S.M.; Derakhshan, N.M.; Khaniani, M.S.; Alivand, M.R. Downregulation of HDAC2 and HDAC3 via oleurope in as a potent prevention and therapeutic agent in MCF-7 breast cancer cells. J. Cell Biochem. 2019, 120, 9172-9180. [CrossRef] [PubMed]

38. Lucas, J.; Hsieh, T.H.; Halicka, H.D.; Darzynkiewicz, Z.; Wu, J.M. Upregulation of PD L1 expression by resveratrol and piceatannol in breast and colorectal cancer cells occurs via HDAC3/p300 mediated NF kB signaling. Int. J. Oncol. 2018, 53, 1469-1480. [CrossRef] [PubMed]

39. de la Rica, L.; Rodríguez-Ubreva, J.; García, M.; Islam, A.B.M.M.K.; Urquiza, J.M.; Hernando, H.; Christensen, J.; Helin, K.; Gómez-Vaquero, C.; Ballestar, E. PU.1 target genes undergo Tet2-coupled demethylation and DNMT3b-mediated methylation in monocyte-to-osteoclast differentiation. Genome Biol. 2013, 14, R99. [CrossRef] [PubMed]

40. Seritrakul, P.; Gross, J.M. Tet-mediated DNA hydroxymethylation regulates retinal neurogenesis by modulating cell-extrinsic signaling pathways. PLoS Genet. 2017, 13, e1006987. [CrossRef]

41. Liu, X.; Lu, H.; Chen, T.; Nallaparaju, K.C.; Yan, X.; Tanaka, S.; Ichiyama, K.; Zhang, X.; Zhang, L.; Wen, X.; et al. Genome-wide analysis identifies Bcl6-controlled regulatory networks during T follicular helper cell differentiation. Cell Rep. 2016, 14, 1735-1747. [CrossRef]

42. Mesnage, R.; Arno, M.; Costanzo, M.; Malatesta, M.; Séralini, G.E.; Antoniou, M.N. Transcriptome profile analysis reflects rat liver and kidney damage following chronic ultra-low dose Roundup exposure. Environ. Health 2015, 14, 70. [CrossRef] [PubMed]

43. Livak, K.J.; Schmittgen, T.D. Analysis of relative gene expression data using real-time quantitative PCR and the 2(-Delta Delta C(T)) method. Methods 2001, 25, 402-4208. [CrossRef] [PubMed] 